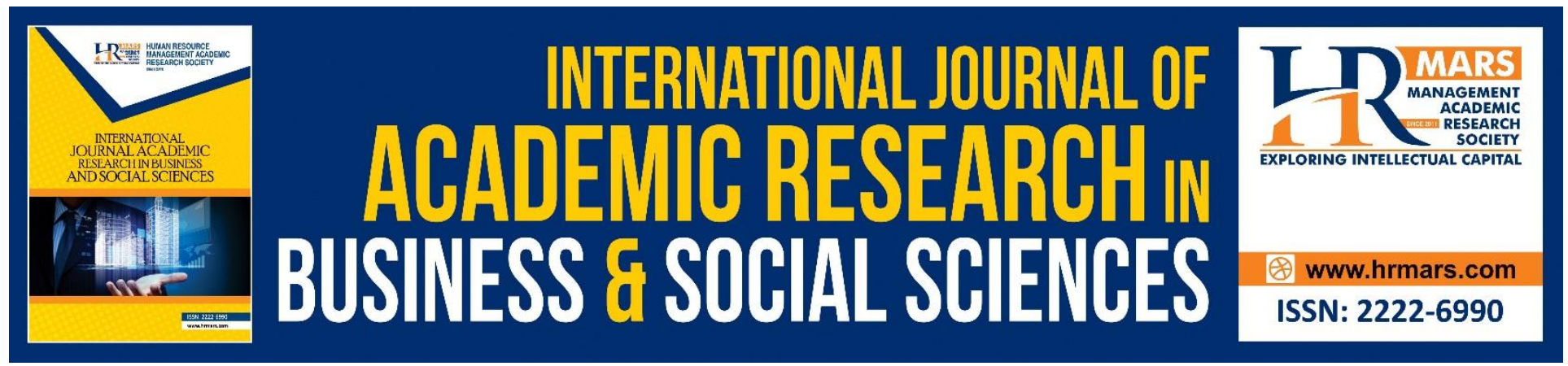

\title{
Remedies for Elder Abuse Victim under Islamic Family Law in Malaysia
}

Asiah Bidin, Noraida Harun, Kamaliah Salleh, Noor 'Ashikin Hamid

To Link this Article: http://dx.doi.org/10.6007/IJARBSS/v9-i3/5704 DOI: $10.6007 /$ IJARBSS/v9-i3/5704

Received: 23 Feb 2019, Revised: 30 March 2019, Accepted: 09 April 2019

Published Online: 16 April 2019

In-Text Citation: (Bidin, Harun, Salleh, \& Hamid, 2019)

To Cite this Article: Bidin, A., Harun, N., Salleh, K., \& Hamid, N. 'Ashikin. (2019). Remedies for Elder Abuse Victim under Islamic Family Law in Malaysia. International Journal of Academic Research in Business and Social Sciences, 9(3), $439-448$.

Copyright: (C) 2019 The Author(s)

Published by Human Resource Management Academic Research Society (www.hrmars.com)

This article is published under the Creative Commons Attribution (CC BY 4.0) license. Anyone may reproduce, distribute, translate and create derivative works of this article (for both commercial and non-commercial purposes), subject to full attribution to the original publication and authors. The full terms of this license may be seen

at: http://creativecommons.org/licences/by/4.0/legalcode

Vol. 9, No. 3, 2019, Pg. $439-448$

http://hrmars.com/index.php/pages/detail/IJARBSS

JOURNAL HOMEPAGE

Full Terms \& Conditions of access and use can be found at http://hrmars.com/index.php/pages/detail/publication-ethics 


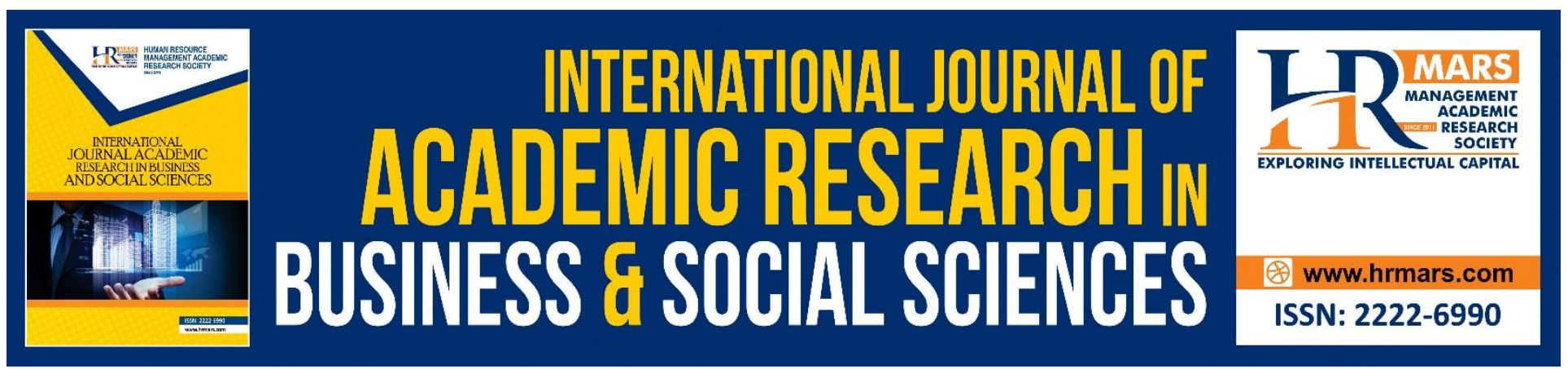

\title{
Remedies for Elder Abuse Victim under Islamic Family Law in Malaysia
}

\author{
Asiah Bidin \\ Faculty of Law and International Relations, University Sultan Zainal Abidin (UniSZA), Gong Badak \\ Campus, 21300 Kuala Nerus, Terengganu, Malaysia \\ Noraida Harun \\ Faculty of Law and International Relations, University Sultan Zainal Abidin (UniSZA), Gong Badak \\ Campus, 21300 Kuala Nerus, Terengganu, Malaysia \\ Kamaliah Salleh \\ Faculty of Law and International Relations, University Sultan Zainal Abidin (UniSZA), Gong Badak \\ Campus, 21300 Kuala Nerus, Terengganu, Malaysia \\ Noor 'Ashikin Hamid \\ Faculty of Law and International Relations, University Sultan Zainal Abidin (UniSZA), Gong Badak \\ Campus, 21300 Kuala Nerus, Terengganu, Malaysia
}

\begin{abstract}
Background: Elder abuse is a serious social problem that is a growing concern. In Malaysia, there is no specific legislation dealing with the issue of elder abuse but, abuse of the elderly is recognized as a form of domestic violence. The legislation dealing with matters pertaining to domestic violence are Domestic Violence Act 1994 (Act 521) (DVA) and Penal Code. These statutes are applicable to both Muslims and non-Muslims. Despite the growing literature on the issue of elder abuse in Malaysia and the legal protections offered by the DVA to the elderly victims, little has been written on the protections of the elderly abused victims among Muslims as provided under the under Islamic family law. Objective: This paper aims to explore the remedies available to the abused elderly provided under the Islamic Family Law (Federal Territories) Act 1984. Results: Syariah courts in Malaysia has jurisdiction to hear cases pertaining to family conflicts. The elderly Muslim wife who becomes a victim of domestic abuse can apply for orders in court for dissolution of marriage due cruelty or neglect of maintenance by husband. Besides, the neglected elderly parents have a right to claim maintenance
\end{abstract}


from their children. Conclusion: The Islamic Family Law (Federal Territories) Act 1984 gives rights to the victims of domestic abuse to seek remedies for dissolution of marriage (in the case of a husband and wife) and to seek an order for maintenance in the case of parents.

\section{Introduction}

In Malaysia, the elderly are those who have reached the age of 60 years, following the ruling on the resolution of the United Nations (UN) in World Assembly on Ageing in Vienna in 1982 (Selvaratnam, et al., 2009). It is undeniable fact that the elderly belong to a group of citizens who are at risk of and vulnerable to violence and crime. Due to their old age and vulnerability compared with younger people, they often being victimized by criminals or unscrupulous individuals. Several challenges faced by the elderly these days are discrimination, poverty, crime and abuse. In Malaysia, abuse of the elderly is classified as a form of domestic violence. Generally domestic violence are all types of violence committed against any member of the family including spouse, children, the elderly or any member of the family. Previously, domestic violence is frequently associated with abuse of wife and children. However, the elderly nowadays were not spared from becoming victims of domestic violence.

\section{Methodology}

This concept paper aims to explore the remedies available to the elderly as provided in the Islamic Family Law (Federal Territories) Act 1984 (Act 303). The provisions in the Enactment will be analyzed to highlight the rights given to the elderly abused victim to seek the remedies available in the Act.

\section{Definition of Elder Abuse}

So far, there has yet to be any specific definition of elderly abuse which is accepted globally (Fallon, 2006). Abuse of the elderly is indeed a very complex issue because it can be studied from various perspectives, according to different disciplines or fields of specialization of the study (Department of Justice, 2009). In addition to the diversified disciplines, the issue is often examined from the local community's perspective. Thus, it resorts to different results based on the perspective of the researcher. Harsh treatment or verbal abuse against the elderly may be considered as an act of abuse in a society, but it may possibly be regarded as a normal treatment in a different community. In view of different disciplines and insights as well as culture of a society, it is difficult to come out with one definition of elder abuse which can be accepted worldwide. According to The Social Services Inspectorate of the UK Department of Health (UK Social Services Inspectorate, 1993), abuse may be described as "physical, sexual, psychological or financial. It may be intentional or unintentional or the result of neglect. It causes harm to the older person,either temporarily or over a period of time". In a report by SAVE Project by Lewisham Social Services (1995), it was stated that "abuse is the physical, psychological or financial mistreatment of an older person by an individual, who has a relationship with them. The abuse is a violation of a person s human and civil rights causing distress. The violation can manifest itself once orrepeatedly".

Although there are various definitions given, most researchers are more inclined to use the definition given by Action on Elder Abuse in the United Kingdom which has also been adopted by the 
International Network for the Prevention of Elder Abuse in the United States, ie "Elder abuse is a single or repeated act, or lack of appropriate action, occurring within any relationship where there is an expectation of trust which may cause harm or distress to an older person" (Krug et al., 2002). In contrast to the two previous definitions that include the types of abuse and the effects of the actions to the elderly as an element in the definition of abuse, the definition used by the Action on Elder Abuse tends to define elder abuse as a breach of one's trust against a victim. When there is a trust relationship between a person and an elderly, breach of the latter's trust will result into a condition called abuse. The trustee is usually composed of children or any person who is responsible in taking care of the elderly.

\section{Types of Elder Abuse}

Elder abuse may occur within domestic settings and in institutions. For domestic abuse, perpetrators of abuse are usually comprised of family members such as children, siblings, in-laws and other caregivers who have family relationship with the victim. The elderly living in institutions or care centers can also become victims of abuse either by their children, staff as well as fellow inmates at the institution. The American Psychological Association (2012) divides the abuse of the elderly into five types; physical abuse, psychological or emotional abuse, financial or material abuse, sexual abuse and neglect, while the National Center on Elder Abuse (1998) had included abandonment and self neglect as another types of elder abuse. Physical abuse refers to the suffering from pain, injury or physical coercion on the elderly. The elderly, who are being kicked, slapped, pushed roughly or being subject of other forms of physical severity are victims of physical abuse. The elderly are victims of psychological/ emotional abuse when the perpetrator does any acts which leads to mental, emotional suffering or which causes fear in them. Psychological/ emotional abuse can be committed verbally or through non-verbal acts. Some examples of psychological abuse via verbal acts are harassment, calling them rudely, using harsh words or other kinds of acts that can leave emotional impact on the elderly. Psychological abuse which is not in verbal form includes obstruction of the elderly's freedom to socialize and isolation from family or friends. Normally they are not allowed to communicate with the surrounding communities. Another form of abuse is sexual abuse where it involves abusive acts such as intimidation, coercion or inability of a person to give consent to a sexual act. Financial abuse or material exploitation on elderly happens when there is an improper or illegal exploitation or use of money, funds or other resources belonging to the elderly. Neglect involves failure of a caregiver to provide the basic needs of the elderly person. This situation can also occur where the caregiver leaves the elderly alone at home and neglects her in terms of self-care, health or hygiene. Abandonment happens when the frail elderly has been left alone or deserted by family members. Another type of abuse is self-neglect. Self-neglect refers to the act of neglect by an elderly against his own-self. This situation occurs when an elderly person neglects his own condition by not taking care of himself, hygiene, or refuses to take medication as prescribed by a doctor or refuses to take a proper food.

\section{Elder Abuse in Malaysia}

Elder abuse is a global issue. Most countries with large populations of elderly are experiencing this problem. The incidence of abuse has been detected as early as 1975 (Krug et al., 2002) yet in 
Malaysia, the issue is still considered as a new. Even so, it has been recognized as a social problem (Mohd Anshari, 2007) and a crime in society (Mohd Yusoff, 2010). Despite the increasing number of studies carried out on the issue of elder abuse, the writings are still limited in Malaysia. Apart from the lack of research and writing, the issue is not much discussed openly by social activists and local academics. Hence, not much information is made known to the public relating to the issue. In Malaysia, study on abuse of the elderly is still considered to be in its early stage. Most cases of abuse are not fully disclosed due to several factors such as constraints in getting real data, the difficulty of identifying cases of abuse and also the refusal of the elderly to reveal their cases. Elder abuse incidence is less exposed in the mainstream media in Malaysia (Mohd Yusoff, 2009). Thus, the extent of the problem of abuse against the elderly in the country cannot be evidently identified. Malaysia is expected to face the problems of elderly abuse in a near future when it becomes an ageing country. Therefore, Malaysia should learn from the experiences of other countries in dealing with the increasing population of the elderly.

\section{Remedies for the Victims under Islamic Family Law (Federal Territories) Act 1984}

Discussion on remedies or rights of victims of domestic violence is oftenly founded on the Domestic Violence Act 1994 (DVA 1994). No doubt, victims of domestic violence such as spouse, children, the elderly or anyone in their family members can apply to court to seek protection from being further abused by other family members. The court may grant an order of protection, either temporarily or permanently to the victim of violence. Additionally DVA 1994 also provides for the rights of the victim to claim compensation from the abuser. DVA 1994 is the Act which is applicable to both Muslim and non-Muslim citizens.

As for Muslims, besides DVA 1994, any victim of domestic violence may also apply to the Syariah Court under Islamic Family Law. This is because, domestic violence is considered as family matters, thus, for Muslim, the Syariah court has jurisdiction to hear cases pertaining to family conflicts. The DVA 1994 provides remedies to the victims by stipulating the rights to apply for protection for shelters as well as compensation for accruing damages consequence to the violence within the family. In contrast, the Muslim can apply for orders in relation to marriage provided under Islamic Family Law in every state in Malaysia. The discussion in relation to this issue will highlight the rights of the elderly to make a claim under the Islamic Family Law (Federal Territories) Act 1984 (Act 303).

The Act 303 is an Act which entitles the elderly to claim for mal (other than criminal) cases. It specifically stipulates provisions concerning marriage, divorce, custody and other matters of Muslim family life. There are two statutory provisions in the Act 303 which are relevant to victims of domestic violence. Section 52(1) gives a right to the wife to apply for dissolution of her marriage or also known as fasakh due to certain reasons caused by her husband. Section 60 gives rights to parents to claim maintenance from the children. It should be noted that these provisions are very general and do not specifically mention the rights of the elderly. However, the provisions also apply to cases of elderly women who become victims of abuse by her husband or a claim by elderly parents who become victims of physical abuse and neglect of maintenance by their children. Below are the rights provided 
by Act 303 to any victims of domestic violence particularly in the case of cruelty or physical abuse and neglect of maintenance.

1. Right to Apply for Dissolution of Marriage (Fasakh) due to Neglect or Cruelty by Husband Section 52(1) (h) outlines some circumstances where a wife is allowed to apply fasakh in cases of abuse by her husband. According to this section, a wife can apply to the Syariah Court to dissolve her marriage or to apply fasakh if her husband habitually assaults her or makes her life miserable by acts of cruelty; or associates himself with immoral women or lives out vile behaviour according to Islamic Law ; or forces the wife to live in an immoral life; or disposes the wife's property or prevents her from using her rights in law over the property; or obstructs her in the observance of obligations or duties or practice of the religion; or if he has more than one wife, he does not treat her equally in accordance with the requirements of Islamic Law. This section does not specifically outline the rights of the elderly but it is understood that any women regardless of age may invoke the provisions if they are experiencing any of the above conditions. The conditions set out in the provisions can be regarded as abusive towards the physical or emotions or psychology of the wife if committed by a husband.

There are several cases in which the court allowed the application for a wife to dissolve the marriage based on the provisions in section 52(1) of the Act. Though the cases initiated by the wife at the Syariah Court under such provisions do not include those who are elderly, this right is granted to all spouses regardless of age. In the case of Hairun binti Mohd Sharif vs. Omar bin Mohd Noor [2004] CLJ (Sya) 75, the appellant in this case applied for dissolution of marriage by way of fasakh under section 52 (1) of the Family Law of the Islamic State Selangor 1984 on the ground that the respondent (her husband) had abused and beat her. The medical report submitted supports the appellant's claim, in which it proved that the blows by the respondent had caused wounds and bruises on the appellant's body. The judge acknowledged that abuses committed by the respondent was a form of persecution under the Islamic law, but was of the view that there was no sufficient evidence to suggest that the responded had constantly hurt the appellant as required under section 52(1) (h) Enactment. Therefore the appellant's application for fasakh was dismissed by the court. The appellant appealed against this decision. In allowing the appeal, the court held that the injuries suffered by the appellant and the physical blows by the respondent are a vicious blows that should not be done by a husband on his wife. It is obvious that such blows sufficiently proved the persecution on the appellant according to Islamic law.

Meanwhile, in the case Rosliah bint Abu Kassim vs. Abdul Rahman bin Ibrahim [2004] CLJ (Sya 270, the wife applied for dissolution of marriage due to ongoing conflicts. The issue to be decided by the court was whether the situation described as continuous dispute fall within the meaning of suffering, which entitled the wife to seek the dissolution of marriage. The appellant claimed that the respondent (her husband) was irresponsible, had beaten her and threatened to kill her. Evidence was submitted to show that the marriage of the appellant and the respondent was always in a state of tension, where they often involved in disputes and quarrels. The judge in this case has allowed an appeal by the wife and decided: 
Marriage is built on the virtuous ground and not on persecution. Even divorce is not encouraged in Islam; no one should be forced to suffer in a marriage that one does not like. In other word, if a marriage has failed and if its aims are not achievable, what more if it causes harm, hardships, suffering, quarrels and fights, then to separate in kindness is better as a solution.

Through the provision of section 52(1)(h)(iv), right to apply fasakh is also available for the wife if the husband had committed financial exploitation against her. A wife is allowed to apply for dissolution of marriage if her husband disposes her property or prevents her from using her legal rights over her property. In the case Ruhaida Che binti Othman vs Nora'zam bin Noordin [2012] 1 CLJ (Sya) 262, the plaintiff (wife) applied for fasakh on the ground that her husband had disposed her property. In other words her husband had committed abuse or financial exploitation on his wife. During crossexamination, the defendant admitted that he had pawned a necklace belonging to the plaintiff twice. The necklace was bought by the plaintiff herself at a price of RM3,000. During the second time he pawned it, the defendant did not redeem it. The court allowed the petition for dissolution of marriage by the plaintiff and held that subsection 49(1) of the Administrative Law of Islam (Terengganu) Act 1985 provides for the grounds that allows for court order to dissolve a marriage. Based on the facts of this case and the provisions of Islamic Law, adopted by the plaintiff, the reason for this application was within the list in the subsection.

2. Right to Apply for Dissolution of Marriage (Fasakh) due to Neglect of Maintenance by Husband A wife is entitled to receive maintenance from her husband. Maintenance of a spouse is obligatory on every husband. Maintenance refers to the basic need of a person such as food, accommodation and clothing. Failure on the part of the husband to give maintenance, his wife is entitled to apply for dissolution of marriage. Section $52(1)$ (b) provides that a wife has the right to apply to the court to dissolve the marriage if her husband has neglected or failed to provide her maintenance for a period of three months. Subsection (d) of the same provision stipulates the right of the wife to apply for fasakh if the husband does not fulfill the conjugal obligation of marriage without reasonable cause for a period of one year. The court in the case Ayu Indira Seak Pei Tang vs. Abdullah Mohd Rosli bin Sahid [2006] 1 CL (Sya) 298 had allowed the dissolution of marriage on the failure of the husband to provide maintenance for three years.

3. Rights to Claim Maintenance by Parents against Children

If the liability to provide maintenance for the spouse is on the husband, Islam requires that children with sufficient financial ability to maintain their parents who are not able to earn their own living. Among the maintenance required on the parents are shelter, clothing, food and health. In al-Quran 65:7, Allah says:

Lodge them during the prescribed period in the houses wherein you dwell, according to the best of your means; and harass them not that you may create hardships for them. And if they be with child, spend on them until they are delivered of their burden. And if they give suck to the child for you, give them their recompense, and consult with one another in kindness; but 
INTERNATIONAL JOURNAL OF ACADEMIC RESEARCH IN BUSINESS AND SOCIAL SCIENCES

Vol. 9, No. 3, March, 2019, E-ISSN: 222 2-6990 ¿ 2019 HRMARS

if you meet with difficulty from each other, then another woman shall suckle the child for him (the father).

If all the conditions set forth in Islam are met, it becomes the responsibility of the children to provide maintenance for their parents. Failure to fulfill such obligation will give rights to the parents to apply to court for maintenance. This right is given based on the provisions of section 60 of Act 303 which empowers the court to order in favor of one's maintenance. Section 60 states:

The Court may order any person liable thereto according to Hukum Syara', to pay maintenance to another person where he is incapacitated, wholly or partially, from earning a livelihood by reason of mental or physical injury or ill-health and the Court is satisfied that having regard to the means of the first-mentioned person it is reasonable so to order.

As far as the maintenance claim by elderly parents is concerned, in the case of Kassim bin Othman \& Fatimah binti Salleh vs Raja Suzana binti Raja Kasim \& Zul Azli bin Hashim [2010] 3 LNS 8, the plaintiffs claimed maintenance from his son and the daughter in law pursuant to the provisions of section 61 of the Islamic Family Law (Negeri Sembilan) Enactment 2003. Plaintiffs in this case had pleaded inter alia that the defendants are to feed them during their lifetime, are allowed to stay at home that they claimed for their whole lives, are allowed to move freely and reasonably and perform their activities in the house and the surrounding area as well as the right to be visited by other children. In allowing the plaintiffs' claims, the court has given a judgment among others that the two defendants should maintain both the plaintiffs (both parents and parents-in-law) during their lifetime. Plaintiffs were also allowed to stay in their homes with rent paid by the defendants and allowed to move reasonably and freely. Earlier in the case of Khalil bin Ahmad v Kamal bin Khalil [2004] CLJ (Sya) 451, the plaintiff, an elderly father has applied to the court for the right to maintenance which had been neglected by his son since the past ten years. The plaintiff had sought payment of RM500 per month, arrears of maintenance of RM36,000 for a the neglected period of ten years and claimed RM2,000 for settlement of medical debt of the defendant's stepmother who was critically ill. In allowing part of the plaintiff's claim, the court ruled that provision on money for life expenditure for parents is obligatory on the children subject to conditions, including (i) that the child has spare in terms of food, clothing and his own families and dependents; and (ii) the parents do not have wealth. Taking into consideration the facts and circumstances as well as the defendant's ability and income, the court decided that the defendant should pay a sum of RM2,000 for medical debt and pay the balance of RM200 every month to the plaintiff (father) as maintenance.

The above two cases portray that the court will allow the claim for maintenance by parents, especially those who are not able to earn their own living. Under such circumstances, the children will be made accountable to provide maintenance to both of their parents. 


\section{Conclusion}

Based on the above discussion, it can be said that the elderly who are Muslims and suffer from physical abuse, financial abuse or neglect of maintenance have the right to make an application to Syariah Court to seek remedies for the abuse he suffered. For victims of abuse, in addition to the rights provided under the civil law, they are also entitled to make an application for any remedies under the governing family laws of their respective states. The law gives rights to the victims of domestic abuse to seek remedies of fasakh or dissolution of marriage (in the case of a husband and wife) and to seek an order for maintenance in the case of parents.

\section{Corresponding Author}

Asiah Bidin, Faculty of Law and International Relations, Universiti Sultan Zainal Abidin (UniSZA), Gong Badak Campus, 21300 Kuala Nerus, Terengganu, Malaysia.

Email: asiah@unisza.edu.my.

\section{References}

American Psychological Association. (2012). Elder Abuse and Neglect - In Search of Solutions. Washington: American Psychological Association

Department of Justice Research Report. (2009). Legal definitions of Elder Abuse and Neglect. http://www.justice.gc.ca/eng/rp-pr/cj-jp/fv-vf/elder-aines/def/elder_abuse-eng.pdf

Selvaratnam, D. P. et al. (2009). Kesan Peningkatan Jangka Hayat di Malaysia. Prosoding PERKEM IV (1): 305-315.

Fallon, P. (2006). Elder abuse and/ or neglect - Literature Review https://moodle.unitec.ac.nz/pluginfile.php/145247/mod_resource/content/0/elder-abuseneglect-report.pdf

Mohd Yusoff, J.Z. (2009). Jenayah dalam Keluarga: Penderaan dan Pengabaian Warga Tua di Malaysia. Paper Presented at International Conference on Corporate Law (ICCL), Surabaya, Indonesia.

Mohd Yusoff, J.Z. (2010). Jenayah Keganasan Rumah Tangga. Edisi Kedua. Kuala Lumpur: Penerbit Universiti Malaya.

National Center on Elder Abuse. (1998). National Elder Abuse Incidence Study. Washington DC: American Public Human Service Association.

Mohd Anshari, R. (2007). Elder Abuse: An Issue to be Recognised and Eliminated. Jurnal Kerja Sosial Malaysia. 6 (1): 1-16.

SAVE Project, Lewisham Social Services. (1995). Adult Protection Procedures. London: Lewisham Social Services. 
INTERNATIONAL JOURNAL OF ACADEMIC RESEARCH IN BUSINESS AND SOCIAL SCIENCES

Vol. 9, No. 3, March, 2019, E-ISSN: 222 2-6990 @ 2019 HRMARS

UK Social Services Inspectorate. (1993). No Longer Afraid. The Safeguard of Older People in Domestic Settings. Practice Guidelines. London: MHSO. 